DOI: http://doi.org/10.21009/JKKP.082.03

\title{
PENERIMAAN DIRI WARGA LANJUT USIA YANG HIDUP SENDIRI
}

\author{
Dyah Ayu Permatasari'1), Clara R.P. Ajisuksmo ${ }^{2 *}$ \\ ${ }^{1,2}$ Fakultas Psikologi, Universitas Katolik Indonesia Atma Jaya \\ ${ }^{2}$ Pusat Kajian Pembangunan Masyarakat, Universitas Katolik Indonesia Atma Jaya \\ Jalan Jenderal Sudirman 51, 12930 Jakarta Indonesia \\ Email: clara.as@atmajaya.ac.id
}

\begin{abstract}
Abstrak
Penelitian ini bertujuan untuk memperoleh gambaran penerimaan diri warga lanjut usia yang tinggal seorang diri, serta faktor apa saja yang mempengaruhi penerimaan diri mereka. Penelitian ini dilakukan dengan menggunakan pendekatan kualitatif yaitu wawancara kepada empat partisipan (dua berjenis kelamin laki-laki dan dua berjenis kelamin perempuan) yang tinggal seorang diri dengan rentang usia 60-70 tahun. Penerimaan dan pemahaman akan diri diungkapkan dalam aspek perasaan sederajat dengan individu lain, percaya dengan kemampuan diri, bertanggung jawab, berorientasi keluar diri, berpendirian, menyadari keterbatasan dan menerima sifat-sifat kemanusiaan dirinya. Faktor yang mendukung penerimaan diri yang tinggi adalah pemahaman diri yang baik, nilai-nilai religiusitas, dan sikap masyarakat sekitar yang mendukung kehadiran mereka. Penerimaan diri yang rendah disebabkan oleh faktor, ketidakberhasilan diri meraih impian atau harapan, kurangnya dukungan sosial dari anak, dan kondisi ekonomi yang lemah.
\end{abstract}

Kata kunci: dukungan sosial, lanjut usia, penerimaan diri

\section{Self-Acceptance of Elderly Who Live Alone by Themselves}

\begin{abstract}
This study aims at obtaining description of self-acceptance of elderly who live alone by themselves, as well as factors that affect their self-acceptance. This study implemented a qualitstivee approach by interviewing four participants, two males and two femaleswith age range of 60-70 years. Self-acceptance and self-understanding were measured by aspects of feeling equal with others, having self-confidence, being responsible, outward looking and open minded, having self-determination, realizing to self limitations, and accepting the characteristics as a human. Factors that support high self-acceptance are good self-understanding, religiousity, and the attitude of their surrounding that support their presence. Low self-acceptance is caused by failure to achieve dreams and hopes, lack of social support from their children, and weak economic conditions.
\end{abstract}

Keywords: elderly, self-acceptance, social support

\section{PENDAHULUAN}

Data Badan Pusat Statistik (BPS) menunjukkan bahwa dalam kurun waktu antara tahun 1971 sampai dengan 2020, jumlah penduduk usia lanjut usia (lansia) di Indonesia meningkat. Hal ini dipengaruhi oleh meningkatnya harapan hidup dan menurunnya angka kematian sebagai dampak dari kemajuan di bidang kesehatan. Pada tahun 2020 jumlah penduduk lansia di Indonesia ada sebanyak 9,92 persen atau 26,82 juta orang, dengan rincian lansia perempuan sebanyak 10,43 persen dan lansia laki-laki 9,42 persen (Badan Pusat Statistik, 2020). Menurut BPS, jumlah terbesar yaitu sebanyak 64,29 persen adalah lansia pada kategori lansia muda yaitu lansia yang berusia 60-69 tahun. Sementara itu, jumlah lansia madya yaitu lansia yang berusia 70-79 tahun ada sebanyak 27,23 persen, dan lansia tua yaitu lansia yang berusia lebih dari 80 tahun ada sebanyak 8,49 persen (Badan Pusat Statistik, 2020). 
Pasal 1 Undang Undang No. 13/Th. 1998 tentang Kesejahteraan Lanjut Usia (http://www.bphn.go.id/data/documents/98uu013.pdf) menyatakan bahwa yang dimaksud dengan lanjut usia atau lansia adalah mereka yang telah mencapai usia 60 tahun ke atas. Selanjutnya berdasarkan Undang-Undang tersebut lansia digolongkan sebagai lansia potensial dan lansia tidak potensial. Lansia potensial merupakan lansia yang masih memiliki kemampuan untuk melakukan pekerjaan yang menghasilkan barang dan/atau jasa. Lansia tidak potensial merupakan lansia yang sudah tidak berdaya untuk bekerja mencari nafkah sehingga hidupnya bergantung pada bantuan orang lain. Pada pasal 5 dan 6 Undang-Undang tersebut dinyatakan bahwa warga lanjut usia mempunyai hak dan kewajiban yang sama dalam kehidupan bermasyarakat, berbangsa, dan bernegara. Lansia mempunyai hak untuk mendapatkan pelayanan keagamaan dan mental spiritual, pelayanan kesehatan, pelayanan kesempatan kerja, pelayanan pendidikan dan pelatihan, kemudahan dalam penggunaan fasilitas, sarana, dan prasarana umum, kemudahan dalam layanan dan bantuan hukum, perlindungan sosial dan bantuan sosial. Di sisi lain, lansia juga mempunyai kewajiban untuk a) membimbing dan memberi nasihat secara arif dan bijaksana berdasarkan pengetahuan dan pengalamannya terutama di lingkungan keluarganya dalam rangka menjaga martabat dan meningkatkan kesejahteraannya, b) mengamalkan dan mentransformasikan ilmu pengetahuan, keahlian, keterampilan, kemampuan dan pengalaman yang dimilikinya kepada generasi penerus, serta c) memberikan keteladanan dalam rangka aspek kehidupan kepada generasi penerus.

Warga lansia identik dengan perubahan pada fisik yang menyebabkan gangguan dan keterbatasan fungsi tubuh yang akan tampak jelas, misalnya rambut yang memutih, gigi yang ompong dan kulit yang menjadi keriput. Perubahan fisik pada lansia akan berpengaruh pada kehidupan psikososialnya misalnya merasa tidak dibutuhkan lagi dan disingkirkan dari lingkungan sosial (Kurnianto, 2015; Rahmi, Daharnis \& Syahniar, 2019). Menurut Indriana, Sawitri, Al Karim dan Hanifah (2021) persoalan yang dihadapi oleh kebanyakan lansia adalah kecemasan menghadapi kematian, yang membuat mereka merasa tegang, gelisah, dan bingung akan situasi yang dirasa belum jelas. Jadi, bisa dikatakan bahwa tantangan utama yang dihadapi para lansia dan akan mempengaruhi kesejahteraan hidup mereka bukan hanya kesehatan fisik saja tetapi juga kesehatan mental mereka (Djaja, 2012; Amalia, Zulkarnain, \& Luthviatin, 2017).

Menurut Amalia dkk. (2017) ada empat belas indikator sehat secara mental pada lansia, yaitu 1) pengembangan hobi dan minat, 2) rekreasi secara periodik, 3) mempertahankan ingatan, 4) menjaga rasa percaya diri, 5) menjaga penampilan yang menarik, 6) mengatasi masalah yang rumit, 7) berkunjung ke makam leluhur, 8) sikap menerima lepas jabatan saat purna tugas, 9) menyesuaikan diri dari kematian pasangan hidup, 10) tidak menyesali kejadian tidak baik pada masa lalu, 11) memberikan sistem pendidikan dari orang tua dan diterapkan oleh anak, 12) menjalin kesetiaan dengan pasangan hidup, 13) menjaga keharmonisan hubungan mertua dengan menantu, dan 14) menjalin kedekatan dengan cucu. Keempatbelas indikator tersebut dapat dijadikan acuan dalam memberi dukungan sosial kepada lansia guna kesejahteraan dan kualitas hidup yang lebih baik.

Penelitian terdahulu menunjukkan bahwa berbagai bentuk dukungan yang diberikan keluarga berperan dalam meningkatkan kesejahteraan dan kualitas kehidupan para lansia. Meski penelitian Nauli, Ismalinda dan Dewi (2014) menunjukkan bahwa tidak ada perbedaan dalam hal harga diri antara lansia yang mempunyai dan tidak mempunyai pasangan hidup, sangat disarankan agar keluarga memberi dukungan agar para lansia dapat meningkatkan harga diri mereka. Penelitian Marni dan Yuniawati (2015) menunjukkan bahwa ada hubungan yang positif antara dukungan sosial dan penerimaan diri pada lansia. Demikian pula halnya dengan penelitian yang dilakukan oleh Uraningsari dan Djalali (2016), Murdiyanto dan Gutomo (2017), Priadana dan Sukianti (2019), serta Rahmi, dkk. (2019), yang menunjukkan bahwa dukungan sosial keluarga dan penerimaan diri akan mempengaruhi kebahagiaan dan kesejahteraan mental lansia. Penelitian Yuselda dan Wardani (2016) melaporkan bahwa ada hubungan antara dukungan keluarga yang berupa dukungan emosional, dukungan instrumental, dan penghargaan yang diberikan keluarga terhadap kualitas hidup lansia. 
Menurut Yuselda dan Wardani (2016) warga lansia tidak hanya membutuhkan dukungan finansial saja tetapi juga membutuhkan dukungan instrumental dalam bentuk keberadaan atau kehadiran anggota keluarga dalam perawatan mereka.

Perubahan lokasi tempat kerja dan tempat tinggal menyebabkan lansia terpisah secara fisik dengan anak-anaknya. Sebagai konsekuensinya lansia harus memenuhi kebutuhannya sendiri dan tidak tergantung secara ekonomis dengan anak-anaknya. Dalam situasi tersebut lansia mengalami kekurangan finansial untuk memenuhi kebutuhannya (Sudrajat, Mulyani \& Saikhu, 2019). Dari penelitian Indriana, dkk. (2021) ditunjukkan bahwa daya lenting (resiliensi) warga lansia yang tinggal bersama keluarga lebih tinggi dibandingkan lansia yang tinggal di panti werdha. Demikian pula dengan penelitian yang dilakukan oleh Šare, Ljubičić, Gusar, Čanović dan Konjevoda (2021) yang melaporkan bahwa lansia yang tinggal di panti werdha mempunyai self-esteem yang rendah dan lebih banyak yang mengalami kecemasan dan depresi, dibandingkan lansia yang tinggal di rumah bersama keluarga mereka. Sementara itu, penelitian dari Priadana dan Sukianti (2019) melaporkan bahwa bila para lansia yang tinggal di panti werdha memiliki penerimaan diri yang baik, pandangan positif tentang dirinya, mengakui dan menerima berbagai hal yang baik dan yang buruk dalam dirinya, maka mereka juga akan memiliki kepuasan hidup atau subjective well-being yang baik pula. Dari penelitianpenelitian tersebut dapat diartikan bahwa keluarga mempunyai peran penting untuk memberikan dukungan sosial kepada para lansia.

Permatasari \& Gamayanti (2016) mendefinisikan penerimaan diri sebagai derajat dimana seseorang telah mengetahui dan menerima kelebihan serta kekurangan dirinya sebagai karakteristik yang membentuk pribadinya. Hurlock (dalam Permatasari \& Gamayanti, 2016; Hafiza, Mawarpury, Dahlia \& Khairani, 2019) menjelaskan bahwa penerimaan diri dipengaruhi oleh adanya pemahaman diri, harapan yang realistis, tidak adanya hambatan dari lingkungan, sikap sosial yang positif, tidak adanya stres yang berat, adanya pengaruh keberhasilan, identifikasi dengan orang yang memiliki penyesuaian diri yang baik, perspektif yang luas, pola asuh yang baik pada masa anak-anak, serta konsep diri yang baik. Menurut Wulandari dan Susilawati (2016) individu yang mampu menerima dirinya dengan baik akan mampu membuat dirinya berkembang dan berinteraksi dengan orang di sekitarnya tanpa melihat kelemahan yang dimilikinya. Individu yang menerima dirinya dengan baik akan merasa senang dan puas untuk menjalani hidup dengan segala kondisi fisik maupun psikis yang dialaminya.

Menurut Sheerer (1957) yang kemudian dimodifikasi oleh Berger (dalam Christanty \& Wardhana, 2013) ciri-ciri dari orang yang mempunyai penerimaan dan pemahaman akan diri adalah sebagai berikut: a) nilai-nilai dan standar diri tidak dipengaruhi lingkungan luar, b) keyakinan dalam menjalani hidup, c) bertanggungjawab terhadap apa yang dilakukan, d) mampu menerima kritik dan saran seobjektif mungkin, e) tidak menyalahkan diri atas perasaannya terhadap orang lain, f) menganggap dirinya sama dengan orang lain, g) tidak ingin orang lain menolaknya dalam kondisi apapun, h) tidak menganggap dirinya berbeda dari orang lain, dan tidak merasa rendah diri.

Penelitian Rahmi, dkk. (2019) menunjukkan bahwa penerimaan diri berkaitan erat dengan gender. Menurut Hurlock (dalam Rahmi dkk, 2019) penerimaan diri pada lansia lakilaki berbeda dari penerimaan diri lansia perempuan, dan hal ini akan mempengaruhi sikap, cara pandang, tanggungjawab, fungsi serta posisi para lansia. Penelitian terdahulu melaporkan bahwa penerimaan diri lansia perempuan lebih tinggi daripada penerimaan diri lansia laki-laki (Rahmi, dkk. 2019).

Dengan mengacu pada uraian di atas, dipandang penting untuk melakukan kajian mengenai bagaimana gambaran penerimaan diri lansia yang hidup sendiri. Penelitian ini bertujuan untuk memperoleh gambaran penerimaan diri warga lanjut usia yang tinggal seorang diri, serta faktor apa saja yang mempengaruhi penerimaan diri mereka. Dengan mengacu pada teori Sheerer tersebut di atas, dalam penelitian ini penerimaan dan pemahaman diri lansia diungkapkan dalam aspek 1) perasaan sederajat dengan individu lain; 2) percaya dengan kemampuan diri; 3) bertanggung jawab; 4) berorientasi keluar diri; 5) berpendirian; 6) menyadari keterbatasan; dan 7) menerima sifat-sifat kemanusiaan dirinya. 


\section{METODE}

Penelitian ini merupakan penelitian deskriptif kualitatif, yang bertujuan untuk mengeksplorasi dan memahami secara holistik dan kontekstual mengenai penerimaan diri lansia yang hidup sendiri. Partisipan dari penelitian dipilih secara purposive, yaitu lansia berusia 60 tahun ke atas, berjenis kelamin laki-laki atau perempuan, tinggal di rumah sendiri, dan berstatus duda atau janda baik karena bercerai atau meninggal dunia. Tabel 1 di bawah ini menunjukkan karakteristik partisipan.

Tabel. 1. Karakteristik partisipan

\begin{tabular}{|l|l|l|l|l|}
\hline $\begin{array}{l}\text { Keterangan/bukan nama } \\
\text { sebenarnya }\end{array}$ & \multicolumn{1}{|c|}{ Anen } & \multicolumn{1}{c|}{ Widodo } & \multicolumn{1}{c|}{ Pinah } & Nikmah \\
\hline Jenis kelamin & Lk & Lk & Pr & Pr \\
\hline Usia & 74 & 68 & 72 & 76 \\
\hline Status & $\begin{array}{l}\text { duda } \\
\text { meninggal }\end{array}$ & $\begin{array}{l}\text { duda } \\
\text { meninggal }\end{array}$ & $\begin{array}{l}\text { janda } \\
\text { meninggal }\end{array}$ & $\begin{array}{l}\text { janda } \\
\text { meninggal }\end{array}$ \\
\hline Pekerjaan & pensiun & pensiun & wirausaha & pensiun \\
\hline Lama tinggal sendiri & 2 th & 5 th & 5 th & 5 th \\
\hline Jumlah anak & 4 & 2 & 2 & 4 \\
\hline Jumlah cucu & 8 & 3 & 5 & 1 dan 1 buyut \\
\hline
\end{tabular}

Dalam penelitian ini aspek-aspek penerimaan diri dari lansia yang akan diukur adalah aspek 1) perasaan sederajat dengan individu lain; 2) percaya dengan kemampuan diri; 3) bertanggung jawab; 4) berorientasi keluar diri; 5) berpendirian; 6) menyadari keterbatasan; dan 7) menerim sifat-sifat kemanusiaan dirinya. Ketujuh aspek penerimaan diri tersebut digali melalui wawancara dengan menggunakan protokol wawancara yang disusun oleh peneliti. Sebelum dilakukan wawancara, partisipan penelitian diberi informed consent untuk ditandatangani sebagai bentuk kesediaan untuk berpartisipasi dalam penelitian ini. Seluruh proses wawancara direkam seijin partisipan.

\section{HASIL DAN PEMBAHASAN}

Hasil penelitian ini menunjukkan bahwa ada perbedaan pola dalam ketujuh aspek penerimaan diri dari keempat partisipan penelitian. Hasil wawancara juga menunjukkan adanya perbedaan penerimaan diri lansia laki-laki dan lansia perempuan. Tabel 2 di bawah ini merupakan ringkasan analisis hasil wawancara dengan keempat partisipan terkait ketujuh aspek penerimaan diri mereka sebagai lansia yang hidup sendiri.

Tabel 2. Gambaran ketujuh aspek penerimaan diri keempat partisipan

\begin{tabular}{|c|c|c|c|c|}
\hline Aspek & Anen & Widodo & Pinah & Nikmah \\
\hline $\begin{array}{l}\text { Perasaan } \\
\text { Sederajat } \\
\text { dengan } \\
\text { Individu lain }\end{array}$ & $\begin{array}{l}\text { - Menilai setiap lansia } \\
\text { memiliki perbedaan } \\
\text { kondisi hidup dengan } \\
\text { porsinya masing- } \\
\text { masing } \\
\text { - Menilai dirinya sama } \\
\text { dengan lansia lainnya } \\
\text { yang tinggal bersama } \\
\text { anak } \\
\text { - Tidak membandingkan } \\
\text { dirinya dengan kondisi } \\
\text { hidup orang lain }\end{array}$ & $\begin{array}{l}\text { - Menilai setiap } \\
\text { manusia } \\
\text { memiliki jalan } \\
\text { hidupnya } \\
\text { masing-masing } \\
\text { - Menikmati } \\
\text { perbedaannya } \\
\text { dengan lansia } \\
\text { lainnya yang } \\
\text { tinggal dengan } \\
\text { anak dalam satu } \\
\text { rumah }\end{array}$ & $\begin{array}{l}\text { - Melihat setiap } \\
\text { lansia memiliki } \\
\text { kelebihan dan } \\
\text { kekurangan pada } \\
\text { kemampuannya } \\
\text { - Membandingkan } \\
\text { kondisi hidupnya } \\
\text { dengan lansia lain } \\
\text { yang lebih baik } \\
\text { darinya }\end{array}$ & $\begin{array}{l}\text { - Melihat setiap } \\
\text { lansia memiliki } \\
\text { perbedaan pada } \\
\text { keterbatasannya } \\
\text { masing-masing } \\
\text { - Meyakini dirinya } \\
\text { untuk tetap } \\
\text { semangat } \\
\text { menjalani hidup } \\
\text { dengan } \\
\text { keterbatasannya }\end{array}$ \\
\hline
\end{tabular}




\begin{tabular}{|c|c|c|c|c|}
\hline & & $\begin{array}{l}\text { Menyadari } \\
\text { setiap lansia } \\
\text { memiliki } \\
\text { kelebihan dan } \\
\text { kekurangannya } \\
\text { masing-masing } \\
\text { - Tidak iri dengan } \\
\text { kondisi hidupnya } \\
\text { degan kondisi }\end{array}$ & $\begin{array}{l}\text { - Pasrah menjalani } \\
\text { kekurangann } \\
\text { dalam hidupnya }\end{array}$ & $\begin{array}{l}\text { - Menilai dirinya } \\
\text { berharga dengan } \\
\text { keterbatasan } \\
\text { yang dimiliki }\end{array}$ \\
\hline $\begin{array}{l}\text { Percaya } \\
\text { dengan } \\
\text { Kemampuan } \\
\text { Diri }\end{array}$ & $\begin{array}{l}\text { - Tidak merasa puas } \\
\text { dengan kehidupannya } \\
\text { saat ini karena } \\
\text { penyesalan akan } \\
\text { perilaku di masa lalu } \\
\text { - Masih memiliki } \\
\text { kemampuan untuk } \\
\text { memasak dan } \\
\text { membersihkan rumah } \\
\text { seorang diri }\end{array}$ & $\begin{array}{l}\text { - Puas dengan } \\
\text { kehidupannya } \\
\text { saat ini karena } \\
\text { masih diberikan } \\
\text { kesehatan, } \\
\text { kebutuhan } \\
\text { tercukupi dan } \\
\text { anak-anak } \\
\text { sudah hidup } \\
\text { mandiri } \\
\text { - Masih memiliki } \\
\text { kemampuan } \\
\text { untuk memasak, } \\
\text { memperbaiki } \\
\text { atap rumah yang } \\
\text { bocor seorang } \\
\text { diri dan kuat } \\
\text { untuk } \\
\text { berolahraga }\end{array}$ & $\begin{array}{l}\text { - Puas dengan } \\
\text { kehidupannya saat } \\
\text { ini karena dapat } \\
\text { melakukan segala } \\
\text { sesuatunya sendiri } \\
\text { dengan bebas } \\
\text { - Masih memiliki } \\
\text { kemampuan untuk } \\
\text { memasak dan } \\
\text { membuka usaha } \\
\text { warung makannya } \\
\text { sendiri }\end{array}$ & $\begin{array}{l}\text { - Puas dan } \\
\text { bersyukur } \\
\text { dengan } \\
\text { kehidupannya } \\
\text { saat ini karena } \\
\text { saat ini sudah } \\
\text { memiliki buyut } \\
\text { dan } \\
\text { membesarkan } \\
\text { anak-anaknya } \\
\text { hingga } \\
\text { berkeluarga } \\
\text { sebagai single } \\
\text { parent } \\
\text { - Masih memiliki } \\
\text { kemampuan } \\
\text { untuk memasak, } \\
\text { mencuci dan } \\
\text { menyetrika } \\
\text { pakaian sendiri }\end{array}$ \\
\hline $\begin{array}{l}\text { Bertanggung } \\
\text { Jawab }\end{array}$ & $\begin{array}{l}\text { - Menyadari } \\
\text { konsekuensi untuk } \\
\text { merawat dirinya sendiri } \\
\text { dari penyakit yang } \\
\text { diderita } \\
\text { - Tetap menjalani } \\
\text { konsekuensinya untuk } \\
\text { merawat dirinya sendiri } \\
\text { dan mengerjakan } \\
\text { kegiatan rumah } \\
\text { seorang diri } \\
\text { - Mendapatkan } \\
\text { komentar negatif dari } \\
\text { tetangganya } \\
\text { - Tidak mempedulikan } \\
\text { komentar negatif yang } \\
\text { ada terhadap dirinya }\end{array}$ & $\begin{array}{l}\text { - Tidak } \\
\text { merasakan } \\
\text { adanya } \\
\text { konsekuensi } \\
\text { dalam } \\
\text { kehidupanya } \\
\text { seorang diri } \\
\text { karena } \\
\text { emandang hidup } \\
\text { sebagai rencana } \\
\text { dari Yang Maha } \\
\text { Kuasa } \\
\text { - Tidak } \\
\text { memandang } \\
\text { hidup } \\
\text { menyendiri } \\
\text { sebagai } \\
\text { kesulitan hidup } \\
\text { - Mendapatkan } \\
\text { komentar negatif } \\
\text { dari tetangga } \\
\text { terkait } \\
\text { perbedaan } \\
\text { agama } \\
\text { - Membiarkan } \\
\text { komentar negatif } \\
\text { yang diterimanya }\end{array}$ & $\begin{array}{l}\text { - Menyadari } \\
\text { konsekuensi untuk } \\
\text { mencari nafkah di } \\
\text { usia tua } \\
\text { - Tetap menjalani } \\
\text { konsekuensi } \\
\text { dengan bekerja } \\
\text { untuk memenuhi } \\
\text { kebutuhannya } \\
\text { - Mendapatkan } \\
\text { komentar negatif } \\
\text { serta perlakuan } \\
\text { buruk dari salah } \\
\text { satu tetangganya } \\
\text { - Membiarkan } \\
\text { perlakuan buruk } \\
\text { tetangganya }\end{array}$ & $\begin{array}{l}\text { - Menyadari } \\
\text { konsekuensi } \\
\text { untuk } \\
\text { berkegiatan } \\
\text { seorang diri } \\
\text { dalam kondisi } \\
\text { tubuh yang } \\
\text { lemah } \\
\text { - Tetap menjalani } \\
\text { konsekuensinya } \\
\text { untuk merawat } \\
\text { dirinya sendiri } \\
\text { dan mengerjakan } \\
\text { kegiatan rumah } \\
\text { seorang diri } \\
\text { Tidak } \\
\text { mendapatkan } \\
\text { komentar negatif } \\
\text { dari tetangga } \\
\text { sekitar }\end{array}$ \\
\hline $\begin{array}{l}\text { Berorientasi } \\
\text { Keluar Diri }\end{array}$ & $\begin{array}{l}\text { - Mau berinteraksi } \\
\text { dengan orang sekitar } \\
\text { (berbicara dengan } \\
\text { orang sekitar) } \\
\text { - Senang bergaul dan } \\
\text { berbicara dengan } \\
\text { orang di sekitarnya } \\
\text { - Tidak mengikuti } \\
\text { kegiatan atau acara }\end{array}$ & $\begin{array}{l}\text { - Mau berinteraksi } \\
\text { dengan orang } \\
\text { sekitar } \\
\text { (berbicara } \\
\text { dengan orang } \\
\text { sekitar) } \\
\text { - Senang } \\
\text { berbincang }\end{array}$ & 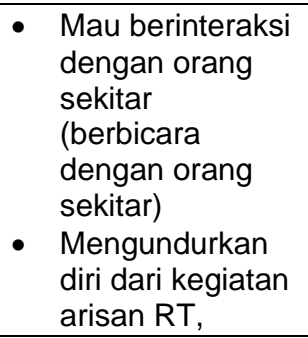 & $\begin{array}{l}\text { - Mau berinteraksi } \\
\text { dengan orang } \\
\text { sekitar } \\
\text { (berbicara } \\
\text { dengan orang } \\
\text { sekitar) } \\
\text { - Jarang berbicara } \\
\text { dengan tetangga } \\
\text { sekitar } \\
\end{array}$ \\
\hline
\end{tabular}




\begin{tabular}{|c|c|c|c|c|}
\hline & $\begin{array}{l}\text { kumpul bersama } \\
\text { tetangga, karena sulit } \\
\text { untuk berjalan, serta } \\
\text { kondisi tubuh yang } \\
\text { tidak sehat }\end{array}$ & $\begin{array}{l}\text { dengan tetangga } \\
\text { sekitar } \\
\text { - Melakukan } \\
\text { kegiatan } \\
\text { bersama warga } \\
\text { sekitar, yaitu } \\
\text { kerja bakti } \\
\text { membersihkan } \\
\text { lingkungan }\end{array}$ & $\begin{array}{l}\text { karena } \\
\text { mendapatkan } \\
\text { perkataan } \\
\text { negatif dari } \\
\text { tetangganya }\end{array}$ & $\begin{array}{l}\text { - } \text { Tidak terlalu } \\
\text { banyak } \\
\text { berkumpul } \\
\text { bersama } \\
\text { tetangga sekitar } \\
\text { - Banyak } \\
\text { melakukan } \\
\text { kegiatan dengan } \\
\text { orang lain di luar } \\
\text { lingkungan } \\
\text { rumahnya (acara } \\
\text { reunian SMA, } \\
\text { dan berkumpul } \\
\text { dengan saudara) }\end{array}$ \\
\hline Berpendirian & $\begin{array}{l}\text { - Pernah kabur dari } \\
\text { rumah karena tidak } \\
\text { ingin tinggal dengan } \\
\text { anak } \\
\text { - Tidak mau } \\
\text { menyusahkan anak, } \\
\text { karena kondisinya di } \\
\text { usia tua } \\
\text { - Ingin merasa bebas } \\
\text { melakukan } \\
\text { kegiatannya seorang } \\
\text { diri } \\
\text { - Tidak mengikuti } \\
\text { permintaan anak untuk } \\
\text { mempekerjakan } \\
\text { pembantu }\end{array}$ & $\begin{array}{l}\text { - Tidak ingin } \\
\text { tinggal dengan } \\
\text { anak, karena } \\
\text { sudah memiliki } \\
\text { tempat } \\
\text { tinggalnya } \\
\text { sendiri } \\
\text { - Ingin merasa } \\
\text { bebas } \\
\text { melakukan } \\
\text { kegiatannya } \\
\text { seorang diri } \\
\text { - Tidak mengikuti } \\
\text { permintaan anak } \\
\text { untuk tinggal } \\
\text { bersama }\end{array}$ & $\begin{array}{l}\text { - Tidak ingin } \\
\text { tinggal dengan } \\
\text { anak, karena } \\
\text { tidak dapat } \\
\text { bebas } \\
\text { melakukan } \\
\text { kegiatan yang } \\
\text { diinginkan } \\
\text { - Tidak nyaman } \\
\text { tinggal dengan } \\
\text { anak }\end{array}$ & $\begin{array}{l}\text { - Tidak ingin } \\
\text { tinggal dengan } \\
\text { anak, karena } \\
\text { ingin mengatur } \\
\text { segala } \\
\text { seuatunya } \\
\text { sendiri, dan tidak } \\
\text { ingin mengatur } \\
\text { maupun diatur } \\
\text { orang lain } \\
\text { - Tinggal seorang } \\
\text { diri untuk } \\
\text { menghindari } \\
\text { pertengkaran } \\
\text { dengan anak } \\
\text { dan menantu } \\
\text { - Tidak mengikuti } \\
\text { permintaan anak } \\
\text { untuk tinggal } \\
\text { bersama } \\
\end{array}$ \\
\hline $\begin{array}{l}\text { Menyadari } \\
\text { Keterbatasan }\end{array}$ & $\begin{array}{l}\text { - } \text { Menyadari kondisi } \\
\text { kesehatan menurun } \\
\text { - Tetap menjalani hidup } \\
\text { dengan } \\
\text { keterbatasannya } \\
\text { - } \text { Menyadari dirinya } \\
\text { yang tidak mampu } \\
\text { berkegiatan dengan } \\
\text { tetangganya (jalan } \\
\text { pagi bersama teman } \\
\text { lansianya) } \\
\text { - Terganggu dengan } \\
\text { keterbatasannya } \\
\text { Tetap melakukan } \\
\text { pekerjaan rumah } \\
\text { seorang diri dalam } \\
\text { kondisi fisik yang } \\
\text { lemah }\end{array}$ & $\begin{array}{l}\text { - Menyadari } \\
\text { keterbatasan } \\
\text { fisik yang } \\
\text { semakin } \\
\text { melemah } \\
\text { - Mensyukuri } \\
\text { kondisinya } \\
\text { - Menjaga } \\
\text { kesehatan tubuh } \\
\text { dengan rajin } \\
\text { berolahraga } \\
\text { setiap pagi } \\
\text { - Terganggu } \\
\text { dengan } \\
\text { keterbatasannya } \\
\text { untuk } \\
\text { berkegiatan } \\
\text { (sulit menyapu } \\
\text { rumah akibat } \\
\text { alergi debu) }\end{array}$ & $\begin{array}{l}\text { - Menyadari } \\
\text { keterbatasannya } \\
\text { dalam } \\
\text { berkegiatan, } \\
\text { dimana } \\
\text { tenaganya mulai } \\
\text { berkurang, sakit } \\
\text { pada sendi kaki } \\
\text { dan tangan, } \\
\text { mudah lelah, } \\
\text { mudah merasa } \\
\text { marah, serta } \\
\text { pelupa } \\
\text { Terganggu } \\
\text { dengan } \\
\text { keterbatasannya } \\
\text { untuk berjualan } \\
\text { Mengoptimalkan } \\
\text { keterbatasannya } \\
\text { dengan } \\
\text { menenangkan } \\
\text { diri }\end{array}$ & $\begin{array}{l}\text { - Menyadari } \\
\text { keterbatasannya } \\
\text { yang tidak } \\
\text { mampu berdiri } \\
\text { lama, berjalan } \\
\text { dengan kursi } \\
\text { roda, akibat } \\
\text { terjatuh di } \\
\text { rumahnya } \\
\text { - Melakukan } \\
\text { rutinitas sehari- } \\
\text { hari yang masih } \\
\text { mampu } \\
\text { dilakukannya } \\
\text { sendiri } \\
\text { (Memasak, } \\
\text { mencuci, } \\
\text { menyetrrika) } \\
\text { - Terganggu } \\
\text { dengan } \\
\text { keterbatasannya } \\
\text { yang sulit } \\
\text { bergerak karena } \\
\text { menggunakan } \\
\text { kursi roda } \\
\text { - Mengoptimalkan } \\
\text { keterbatasannya } \\
\text { dengan berobat } \\
\text { dan melakukan } \\
\text { konsultasi } \\
\text { dengan }\end{array}$ \\
\hline
\end{tabular}




\begin{tabular}{|c|c|c|c|c|}
\hline & & & & $\begin{array}{l}\text { dokternya } \\
\text { secara online }\end{array}$ \\
\hline $\begin{array}{l}\text { Menerina Sifat } \\
\text { Kemanusiaan }\end{array}$ & $\begin{array}{l}\text { - Tidak merasa } \\
\text { kecewa dengan } \\
\text { keputusannya tinggal } \\
\text { seorang diri } \\
\text { - Berterima kasih dan } \\
\text { bersyukur atas } \\
\text { kondisinya saat ini } \\
\text { - Tidak merasa sedih } \\
\text { dan kesepian karena } \\
\text { anak jarang } \\
\text { mengunjunginya } \\
\text { - Tidak menceritakan } \\
\text { perasaannya kepada } \\
\text { anak }\end{array}$ & $\begin{array}{l}\text { - Tidak merasa } \\
\text { sedih dengan } \\
\text { keputusannya } \\
\text { tinggal seorang } \\
\text { diri dan jauh dari } \\
\text { anak } \\
\text { - Tidak merasa } \\
\text { kesepian tinggal } \\
\text { seorang diri } \\
\text { - Mensyukuri } \\
\text { hidupnya tanpa } \\
\text { rasa iri dengan } \\
\text { kondisi lansia } \\
\text { lainnya yang } \\
\text { tinggal dengan } \\
\text { anak dalam satu } \\
\text { rumah } \\
\text { Menceritakan } \\
\text { perasaan dan } \\
\text { kondisinya } \\
\text { kepada anak }\end{array}$ & $\begin{array}{l}\text { - Merasa sedih } \\
\text { karena harus } \\
\text { tetap bekerja, } \\
\text { mencari nafkah } \\
\text { seorang diri di } \\
\text { usia tua } \\
\text { - Tidak merasa } \\
\text { kesepian dengan } \\
\text { tinggal seorang } \\
\text { diri } \\
\text { - Merasa sedih } \\
\text { dengan kondisi } \\
\text { finansial yang } \\
\text { menurun karena } \\
\text { sepinya pembeli } \\
\text { di warung } \\
\text { makannya } \\
\text { Tidak } \\
\text { menceritakan } \\
\text { perasaan } \\
\text { sedihnya kepada } \\
\text { anak } \\
\text { Merasa bahagia } \\
\text { setiap } \\
\text { berkumpul } \\
\text { bersama anak } \\
\text { dan cucunya }\end{array}$ & $\begin{array}{l}\text { - Tidak merasa } \\
\text { sedih dan } \\
\text { kecewa dengan } \\
\text { keputusannya } \\
\text { tinggal seorang } \\
\text { diri } \\
\text { - Terkadang } \\
\text { merasa kesepian } \\
\text { tinggal seorang } \\
\text { diri } \\
\text { - Menyemanagti } \\
\text { dirinya untuk } \\
\text { tidak merasa } \\
\text { sedih karena } \\
\text { kesepian } \\
\text { - Mengalihkan } \\
\text { perhatiannya } \\
\text { untuk melakukan } \\
\text { hal lain agar } \\
\text { tidak merasa } \\
\text { sedih } \\
\text { - Tidak } \\
\text { menceritakan } \\
\text { perasaannya } \\
\text { kepada anak }\end{array}$ \\
\hline
\end{tabular}

Hasil penelitian ini akan diuraikan berdasarkan ketujuh aspek penerimaan diri dari masingmasing partisipan.

1. Perasaan sederajat dengan individu lain

Perbedaan antara lansia yang satu dengan yang lain harus dipandang sebagai hal yang wajar dan tidak boleh menjadikan pemicu untuk memandang diri sendiri secara negatif. Termasuk di dalamnya adalah ada lansia yang tinggal bersama anak, ada lansia yang mampu berlari sementara ada lansia yang tidak mampu berdiri tegak dan harus memakai kursi roda untuk bergerak. Rasa syukur atas anugerah yang diberikan oleh Sang Pencipta menjadi sumber penting untuk menghilangkan rasa kecewa dan ketidakpuasan. Hal ini sejalan dengan yang dinyatakan oleh Budiarti (dalam Rahmawati \& Saidiyah, 2016) bahwa keyakinan yang kuat akan campur tangan Tuhan atas apa yang diperoleh dalam menjalani kehidupan merupakan faktor penting untuk menjadi lansia yang sukses.

"Ya tiap orang ada yang sehat ada yang sakit, tapi ya harus semangat saya, tidak boleh lemah. Kita musti menghargai kita sendiri, kalau kita tidak menghargai, gimana orang lain bisa ngehargain kita? Ya kan? Kita musti tunjukan bahwa kita tuh punya harga diri, kita menghargai diri dan orang juga akan begitu ke kita gitu. Kan kalau kitanya ga ngerhargain kita sendiri, siapa lagi?" (Nikmah)

"Ya kalau kecewa sih opa punya prinsip opa tuh berterima kasih dengan kenikmatan dari Allah. Jangan dibandingkan sama orang yang di atas kita, tapi bandingin yang di bawah kita. Jadi ga ada kekecewaan tuh." (Anen) 
"Saya enggak ga iri itu. Karena manusia sudah mempunyai ini porsi sendiri. dan orang bisa berkumpul dengan keluarga, anak, cucu, saya enggakkan, mungkin jalan saya harus begini. Tapi saya nikmati itu. Enjoy gitu, tenang." (Widodo)

\section{Percaya dengan kemampuan diri}

Percaya dengan kemampuan diri dan tidak tergantung pada orang lain akan membuat lansia menjadi lebih sehat mental. Pengalaman hidup sebelumnya bahwa ia mempunyai kemampuan dan mandiri mempunyai peranan dalam mengkondisikan lansia tetap merasa bersyukur meskipun hidup sendiri. Hal ini sejalan dengan yang dinyatakan oleh Suardiman (dalam Rahmawati \& Saidiyah, 2016) bahwa optimisme dan efikasi diri merupakan salah satu kunci dari kesuksesan di masa lansia.

"Alhamdulilah puas ya. Bukan puas aja, saya bersyukur. Ya bersyukur lah, kita harus bersyukur selalu. Kebetulan dengan kegiatan saya kalau siang itu istilahnya cukup menyita waktu. Itu ga bikin sepi. Kalau malem, itu saya lebih condong banyak nonton TV, terutama yang ada kaitannya dengan istilahnya kegiatan politik gitu." (Widodo)

"Nah sekarang saya sendiri di sini. Ya saya jualan. Kalo buat makan mah ya dapet ya. Saya mah jualan asal bisa buat bayar kontrakan juga saya udah seneng gitu ya. Engga musti aduh saya pusing atau gimana" (Pinah)

"ya memang dari kecil itu, lingkungan saya itu sudah diajari mandiri. Jadi apa-apa dikerjain sendiri." (Nikmah)

\section{Bertanggung Jawab}

Setiap individu harus bertanggungjawab terhadap perilakunya, dan demikian pula dengan para lansia. Termasuk di dalam pertanggungjawaban atas perilaku lansia dalam penelitian ini adalah konsekuensi terhadap keputusan untuk hidup sendiri di masa tua. Merawat diri yang sakit dengan kontrol ke dokter secara rutin, mencari nafkah untuk memenuhi kebutuhan dirinya, melakukan kegiatan yang adakalanya membuat cedera merupakan beberapa contoh yang diungkapkan oleh para partisipan. Menurut Moilanen, Kangasniemi, Papinaho, dkk. (2020) kemandirian pada lansia adalah hal penting dalam perawatan para lansia, dan kemandirian harus dipandang sebagai bagian dari tanggungjawab atas keputusan yang dipilih.

"Seperti sebelumnya waktu istri masih ada, kadang-kadang saya itu ya pak tolong ini belikan ini di pasar, jadi ya kita karena itu tanggung jawab ya beli, dan itu ya tidak seperti kok diperlakukan begitu ya.ja ji hidup seperti ini tuh ga kaget apa-apa sendiri. Waktu anak-anak masih kecil aja, seperti nyuci itu bagian saya, setrika ibunya. Padahal ibunya tuh dah masak, pagi sampe siang kan ngajar. Ya itu kita kerja sama." (Anen)

"Kalo ketentuannya tiap bulan kontrol jantung, kalo asma, kontrol asma. Ada sih Obat dari dokternya kayak jantung dikasih, asma dikasih. Jadi untuk ambil nomor jam 4 pagi ke rumah sakit diperkirakan jam 2 siang balik lagi, kadang-kadang dokternya dateng jam 5. Dari dokter jantung, trus dipindah ke dokter syaraf, terus berpindah-pindah akhirnya makin kecapekan terus jadi makin sakit." (Widodo)

\section{Berorientasi Keluar Diri}

Salah satu aspek penting untuk menjaga kesehatan mental para lansia adalah berorientasi keluar diri dan terbuka terhadap kehadiran orang lain, yang diujudkan dalam bentuk menjalin hubungan yang baik dengan orang-orang di sekitar. Lingkungan tempat tinggal yang baik yang mendukung kehadiran para lansia dengan memperlakukan mereka dengan baik akan sangat mendukung terbentuknya kesejahteraan mental para lansia. Sejalan dengan penelitian yang dilakukan Wang (2009) bahwa keterlibatan para lansia dengan lingkungan sosialnya mempunyai peranan penting terhadap kualitas kesehatan mental mereka. 
"Ya baik-baik semua. Deket, biasa aja kan selagi kita ga punya niat jelek kan ya diterima ya. Cukup baik. Artinya dia cukup baik, sopan, dihormati lah, cukup dihormati. Jadi orang-orang kalo ketemu, temen kalo ketemu dia selalu nyalamin, salaman. Baik lah kalo hubungan dengan tetangga, komunitas masjid, atau temen-temen lansia di Bogor Park bagus. Ya cerita-cerita, ceritanya ga serius. Sambil dibawa humor aja." (Anen)

"Ya aktif, misalnya yuk kita kumpul di rumahnya Pak Burhan, dateng dia, makan bersama gitu. Biasanya Pak Burhan yang masak terus temen-temen ada enam orang tujuh orang makan bersama dan dia selalu hadir." (Widodo)

\section{Berpendirian}

Berpendirian untuk tidak menggantungkan kehidupannya pada anak menjadi hal penting bagi lansia untuk menjaga kesehatan mentalnya. Keputusan untuk menghabiskan masa tua seorang diri dan tidak tinggal bersama anak merupakan satu prinsip yang dipegang oleh lansia untuk menjadi bahagia. Sebagai contoh, salah satu partisipan dari penelitian ini mengungkapkan bahwa bila ia memiliki tempat tinggal sendiri maka dirinya tidak perlu ikut anaknya dan tinggal bersama anak. Lansia merasa lebih bebas dalam mengatur dan menikmati kehidupannya di masa tua. Independensi dan otonomi bagi lansia merupakan hal penting yang harus dihargai karena erat hubungannya dengan kesehatan mental para lansia (Moilanen, Kangasniemi, Papinaho, dkk. (2020)

"Kalau prinsip saya sih, kalau punya tempat sendiri ngapain ikut anak? Enggak, ga jadi beban. Malah boleh dibilang saya itu ga ada temennya itu lebih bebas." (Widodo)

"Iya keputusan saya, karena saya kalau ikut anak saya orangnya gabisa, gimana, gabisa bebas. Kan kitanya mau makan ga enak, gitu ya. Kitanya pengen tidur, ya kalau disitu biar kata menderita, saya mau tidur, saya mau, kalau saya capek saya mau berenti, kalau saya ga kuat ya saya ga jualan." (Pinah)

"Begitu saya mau tidur ya tidur. Kalo sama anak, anak laki saya ngurusin gitu, tapi sana ga enak sama istrinya. Kan istrinya, dia kawin sama orang Muslim. Jadi saya juga udah ga sejalan, jadi saya gamau." (Nikmah)

\section{Menyadari Keterbatasan}

Lansia harus menyadari bahwa fisiknya tidak sekuat ketika ia masih muda. Mereka juga harus menyadari bahwa ada kemunduran kemampuan kognisi serta pengaturan emosi. Menurut Budiarti (dalam Rahmawati \& Saidiyah, 2016) salah satu faktor kesuksesan dalam menjadi lansia adalah sikap positif dengan menyadari segala kekurangan dalam dirinya dengan sikap optimis untuk mencapai tujuan hidup yang lebih bermakna.

"Ya sekarang mah terbatasanya dari tenaganya kurang, suka ada emosi gitu. Kalo dulu mah enggak dek. Sekarang mah suka emosi-emosian. Gatau, dulu mah ga ada. Terus tenaganya juga udah ga kayak dulu ya. Terbatas lah gitu." (Nikmah)

"Ya olahraga yang pantas, ya saya kan kalo olahraga yang berat kan ga bisa. Kalo ya lari atau jalan atau renang bisa" (Widodo)

"Kan sekarang saya orangnya suka pelupa, kita lagi masak, ni ga ada masako, ih garemnya ga ada garem, kita pergi lagi. Kan gitu adanya udah pusing. Entar udah beli ini itu ada lagi yang kelupaan lain. Gitu aja hahaha untung warungnya deket saya." (Pinah)

"Itu di atur sama kondisi kesehatan gitu ya, ya kesehatannya udah begini ya. Opa mah suka berpikir ya mau berbuat begini-begini, inget sama umur. Umur udah ga pantes. Introspeksi diri itu aja. Udah ga pantes gitu ya." (Anen)

7. Menerima Sifat-Sifat Kemanusiaan Dirinya.

Rasa syukur yang dimiliki oleh para lansia mempunyai peranan penting untuk menguatkan mereka menjalani kehidupan sebagai lansia yang hidup sendiri. Rasa syukur ini mempengaruhi keteguhan mereka untuk tidak mengeluh, atau merasa sedih dan kecewa 
atas keputusan mereka tinggal sendiri pada usia tua. Sebagai manusia, dapat dipahami bahwa ada kalanya timbul rasa sepi karena tinggal sendiri. Apabila muncul rasa sepi, seringkali mereka melakukan kegiatan yang dapat membuat mereka sibuk untuk menghilangkan rasa sepi.

"Walau ada kesulitan-kesulitan apa ya karena begini. Kesulitan yang dialami oleh saya ya itu bukan apa-apa, itu ganjaran dari Allah. Ya terima, jalanin. Kan ya pasti kesulitannya banyak yaudah jalanin aja. Jadi ga ada yang disesali, dan dengan jalan ini mudah-mudahan dosa saya diampuni sama Allah. Ya gitu kalo prinsip saya ya." (Anen)

"Enggak ya orang-orang kan punya anak kerja. Ada yang ditentuin kapan ditengokin sebulan sekali atau kapan gitu ya, tapi kan opa mikirnya ya itu waktu dia gabisa, jadi tambahan buat dia urus keluarganya, buat kerja kehidupan dia kedepan. Kalo dia inget ya dateng, kalo ga ya gapapa. Dimana-mana anak juga ga akan lupa sama orang tuanya. Jadi ya kalo dia mau dateng ya dateng. Kita tuh inget anak tuh sibuk ya jadi memakluminya cepet. Jadi inget kegiatan anak-anak saya, ya saya memakluminya cepet, jadi ga keburu kesel." (Nikmah)

\section{SIMPULAN DAN SARAN}

Penelitian ini bertujuan untuk melihat gambaran penerimaan diri pada lansia yang tinggal sendiri. Peneliti menggunakan tujuh aspek penerimaan diri menurut Sheerer dan yang telah dimodifikasi oleh Berger (dalam Christanty \& Wardhana, 2013), yaitu perasaan sederajat dengan individu lain, percaya dengan kemampuan diri, bertanggung jawab, berorientasi keluar diri, berpendirian, menyadari keterbatasan, dan menerima sifat kemanusiaan. Hasil penelitian menunjukkan bahwa, keempat partisipan memiliki pola penerimaan diri yang berbeda dalam pemenuhan ketujuh aspek penerimaan diri tersebut. Dua partisipan menunjukkan pola yang sama, dimana keduanya mampu memenuhi ketujuh aspek penerimaan diri. Namun, dua partisipan lainnya memiliki pola yang berbeda, dimana kedua partisipan tersebut hanya mampu memenuhi enam aspek saja. Aspek yang dapat dipenuhi oleh setiap partisipan, adalah aspek bertanggung jawab, aspek berorientasi keluar diri, aspek berpendirian, aspek menyadari keterbatasan, dan aspek mengenali sifat kemanusiaan. Ada satu partisipan yang tidak mampu memenuhi aspek perasaan sederajat dengan individu lain, serta satu partisipan lainnya yang tidak mampu memenuhi aspek percaya dengan kemampuan diri. Ketidakmampuan yang dimiliki oleh dua partisipan untuk memenuhi tujuh aspek penerimaan diri tersebut disebabkan oleh faktor-faktor yang dialami dalam kehidupan mereka masingmasing.

Penelitian ini menemukan ada faktor lain yang mendukung maupun menghambat lansia dalam menerima dirinya. Faktor-faktor yang mendukung penerimaan diri seseorang meliputi pemahaman tentang diri sendiri, harapan yang realistis, sikap masyarakat yang mendukung, dan religiusitas yang dimiliki lansia. Faktor-faktor yang menghambat lansia untuk menerima dirinya, adalah ketidakberhasilan diri meraih impian atau harapan, kurangnya dukungan sosial dari anak, dan kondisi ekonomi yang lemah. Kondisi ekonomi yang kurang membuat lansia harus bekerja mencari nafkah untuk memenuhi kebutuhan hidupnya seorang diri di usia tua. Tuntutan untuk bekerja di usia tua mengarahkan lansia pada timbulnya pandangan berbeda dengan lansia lain, dan menilai dirinya tidak sederajat dengan lansia lainnya, sehingga la tidak menerima kondisi hidupnya yang berbeda dengan orang lain sebagai salah satu aspek dalam penerimaan diri.

Hasil penelitian ini menunjukkan bahwa keluarga mempunyai peranan penting untuk memberikan perhatian lebih kepada orang tua mereka yang sudah lanjut usia, terlebih lagi bagi orang tua yang tinggal seorang diri (Marni \& Yuniawati, 2015; Uraningsari \& Djalali, 2016; Murdiyanto \& Gutomo, 2017; Priadana dan Sukianti, 2019; Rahmi, dkk., 2019). Meskipun jarak memisahkan lansia dengan keluarganya, pihak keluarga terutama anak perlu mengunjungi orang tua lanjut usia mereka secara teratur atau rutin (Yuselda \& Wardani, 2016). Hal ini dinilai dapat memberikan rasa senang dan rasa dihargai oleh anak, sehingga mereka mampu menjalani kehidupannya dengan bahagia di usia tua. 


\section{UCAPAN TERIMA KASIH}

Ucapan terima kasih diberikan kepada para narasumber dari penelitian ini, atas kesediaan untuk terlibat dalam penelitian ini dan dan waktu yang diberikan.

\section{DAFTAR PUSTAKA}

Amalia, D.I., Zulkarnain, E. \& Luthviatin, N. (2017). Indikator praktik sehat secara mental pada lanjut usia berdasarkan dukungan sosial keluarga (Studi kualitatif di Kabupaten Lumajang). e-Jurnal Pustaka Kesehatan, 5(3), 588-595

Badan Pusat Statistik (2020) Statistik Penduduk Lanjut Usia 2020. Jakarta: Badan Pusat Statistik.

Djaja, S. (2012). Analisis penyebab kematian dan tantangan yang dihadapi penduduk lanjut usia di indonesia menurut riset kesehatan dasar 2007. Buletin Penelitian Sistem Kesehatan, 15(4), 323-330

Christanty, D.A. \& Wardhana, I.S.P. (2013). Hubungan persepsi dukungan sosial dengan penerimaan diri pasien penderita diabetes mellitus pasca amputasi. Jurnal Psikologi Klinis dan Kesehatan Mental, 2 (2), 55-61

Hafiza, S., Mawarpury, M., Dahlia, \& Khairani, M. Subjective Well-being and Self-acceptance among Scavengers. (2019). Subjective well-being and self-acceptance among scavengers. Proceedings of the 1st International Conference on Psychology (ICPsy 2019), July 17-18, 243-248. DOI: 10.5220/0009447202430248

Indriana, Y., Sawitri, D.R., Al Karim, C.H. \& Hanifah, M.I. (2021). Resilience differences towards the elderly reviewed from the living place. IOSR Journal of Humanities and Social Science (IOSR-JHSS), 5 (4), 44-52. www.iosrjournals.org

Kurnianto, D. (2015). Menjaga kesehatan di usia lanjut. Jurnal Olahraga Prestasi, 11(2),19-30. DOI: https://doi.org/10.21831/jorpres.v11i2.5725

Marni A. \& Yuniawati, R. (2015). Hubungan antara dukungan sosial dengan penerimaan diri pada lansia di Panti Wredha Budhi Dharma Yogyakarta. Empathy, Jurnal Fakultas Psikologi, 3(1), 1-7.

Moilanen, T., Kangasniemi, M., Papinaho, O., Mynttinen, M., Siipi, H, Suominen, S. \& Suhonen, R. (2020). Older people's perceived autonomy in residential care: An integrative review. Nursing Ethics, 28(3), 414-434. https://doi.org/10.1177/0969733020948115

Murdiyanto, M \& Gutomo, T. (2017). Peran keluarga dalam mewujudkan lanjut usia sejahtera. Media Informasi Penelitian Kesejahteraan Sosial, 4(1), 1-10 https://doi.org/10.31105/mipks.v41i1.2271

Nauli, F.A., Ismalinda, W. \& Dewi, A.P. (2014). Hubungan keberadaan pasangan hidup dengan harga diri pada lansia. Jurnal Keperawatan Jiwa, 2(1), 24-30. DOl:https://doi.org/10.26714/jkj.2.1.2014.24-30

Permatasari, V. \& Gamayanti, W. (2016). Gambaran penerimaan diri (Self-Acceptance) pada orang yang mengalami skizofrenia. Psympathic, Jurnal IImiah Psikologi, 3 (1), 139 - 152

Priadana, F. I., \& Sukianti, D. S. (2019). Penerimaan diri dengan subjective well-being pada lansia di Panti Werdha. Prosiding Seminar Nasional \& Call Paper Psikologi Sosial 2019: Psikologi Sosial di Era Revolusi Industri 4.0: Peluang \& Tantangan. http://fppsi.um.ac.id/wp-content/uploads/2019/07/Fahrizal-Idham.pdf

Rahmawati, F. \& Saidiyah, S. (2016). Makna sukses di masa lanjut. Psympathic: Jurnal IImiah Psikologi, 3 (1), 51-68. DOI: 10.15575/psy.v3i1.783

Rahmi, A., Daharnis, D. \& Syahniar, S. (2019). Elderly self-acceptance based on gender and residence and its implications to the guidance and counseling services. Journal of Educational and Learning Studies, 2(2), 76-82. DOI: https://doi.org/10.32698/067 
Šare, S., Ljubičić, M., Gusar, I., Čanović, S. \& Konjevoda, S. (2021) Self-esteem, anxiety, and depression in older people in nursing homes. Healthcare, 9, 1035, 1-12. https:// doi.org/10.3390/healthcare9081035

Sheerer, E.T. (1957) The relationship of self-acceptance and self-respect to acceptance of and respect for others. Pastoral Psychology, 8, 35-42. https://doi.org/10.1007/BF01844128

Sudrajat, Mulyani, P. W., \& Saikhu, A. (2019). Perubahan socio-culture dan economic separation keluarga dan pengaruhnya terhadap kehidupan lansia di desa Tileng Kecamatan Girisubo. Majalah Geografi Indonesia, 33(1), 68-78. https://doi.org/10.22146/mgi.41255

UNDANG-UNDANG REPUBLIK INDONESIA NOMOR 13 TAHUN 1998 TENTANG KESEJAHTERAAN LANJUT USIA. http://www.bphn.go.id/data/documents/98uu013.pdf

Uraningsari, F. \& Djalali, M. A. (2016). Penerimaan diri, dukungan sosial dan kebahagiaan pada lanjut usia. Persona: Jurnal Psikologi Indonesia, 5(1), 15-27. https://doi.org/10.30996/persona.v5i01.738

Wang, S-J. (2009). Social Engagement in the Elderly. Journal of The Chinese Medical Association, 72 (10), 64-66.

Wulandari, A. R., \& Susilawati L., K., P., A. (2016). Peran Penerimaan Diri Dan Dukungan Sosial Terhadap Konsep Diri Remaja Yang Tinggal Di Panti Asuhan Di Bali. Jurnal $\begin{array}{lll}\text { Psikologi Udayana, 135-144. } & \text { 3(3), }\end{array}$ http://ojs.unud.ac.id/index.php/psikologi/article/view/28065

Yuselda, M. \& Wardani, I. Y. (2016) Dampak dukungan keluarga terhadap kualitas hidup lansia. Jurnal Keperawatan, 8 (1) 9-13. DOI: https://doi.org/10.32583/keperawatan.8.1.2016.9-13 